\title{
HISTORICAL OVERVIEW OF PASTORAL CARE IN PRISON IN POLAND (1550-1956)
}

\section{INTRODUCTION}

The following article will present history of the Catholic Church in the light of pastoral care in Poland from $15^{\text {th }}$ century. It focuses primarily on the evolution of legal acts regarding prison chaplaincy in Poland. The article will seek to integrate the findings of a few books [CZACKI 1800; RAFACZ 1932; РотоскI 1929, 22-40; SenKowsKa 1961, 142-43] into a new detailed analysis of most important regulations of the prison chaplaincy, various areas of the pastoral care, as well as functioning of prison chapels. Special attention will be paid to analysis of relatively unknown documents: instrukcja $z$ dnia 18 września 1550 r. wydana przez kanclerza koronnego Stanistawa Ocieskiego; dokument wydany w dniu 16 maja 1833 r. Urządzenie tymczasowe porządku i karności więźniów dla więzień, $w$ których fabryki sa zaprowadzone. The analysis of mentioned documents as well the other legal acts ${ }^{1}$ will highlighted the process of forming prison chaplaincy in Poland and evolution of duties of prison chaplain.

Rev. Mgr Michal Czelny - Assistant in Department of Law on Religion, Institute of Legal Sciences, Faculty of Law, Canon Law and Administration, the John Paul II Catholic University of Lublin, Al. Racławickie 14, 20-950 Lublin, Poland; e-mail: michal.czelny@kul.pl; https://orcid.org/ 0000-0003-1420-4090

Ks. mgr lic. Michą Czelny - asystent w Katedrze Prawa Wyznaniowego, Instytut Nauk Prawnych, Wydział Prawa, Prawa Kanonicznego i Administracji Katolickiego Uniwersytetu Lubelskiego Jana Pawła II, Al. Racławickie 14, 20-950 Lublin; e-mail: michal.czelny@kul.pl; https://orcid.org/ 0000-0003-1420-4090

${ }^{1}$ Dekret podpisany przez Józefa Piłsudskiego w dniu 8 lutego 1919 r. w sprawie tymczasowych przepisów więziennych; rozporządzenie Ministra Sprawiedliwości z dnia 20 kwietnia 1926 r. o zaspokajaniu potrzeb religijnych więźniów i o działalności oświatowej, szkolnej i pozaszkolnej w więzieniach; rozporządzenie Prezydenta Rzeczypospolitej z dnia 7 marca 1928 r. w sprawie organizacji więziennictwa; rozporządzenie Ministra Sprawiedliwości z dnia 20 czerwca 1931 r. w sprawie 


\section{THE RELIGIOUS ASSISTANCE IN POLAND FROM MODERN PERIOD}

The beginning of religious assistance in Poland is dated in the feudal period. An important example mentioned by many authors and concerning spiritual accompaniment of prisoners was the Instruction of 18 September 1550 issued by Stanistaw Ocieski [CZacki 1800, 100; BedyŃSKi 1994, 11; NikOlajew 2012, 20], the Chancellor of Poland. This instruction was very progressive, and its goal was to improve the spiritual life of prisoners [Nikołajew 2012, 20].

The precursor of changes to the prison system was pope Clemens XI who opted for establishing the House of St. Michael in Rome in 1703. It was a correction facility for juvenile delinquents whose purpose was to improve the morality of its wards. The daily timetable included time for reflection and contemplation, Bible reading, prayer, R.E. lessons and participation in the sacramental life. It was the first time when the function of an activity organizer - a prison chaplain - appeared [BedyŃsKi 1994, 13; NikoŁaJew 2012, 21]. The establishment of the House of St. Michael in Rome became an inspiration to creating similar correction houses for juvenile delinquents in Warsaw: the House of Correction of St. Michael established in 1732 and founded by Rev. Gabriel Piotr Baudouine and the Correction House set up in 1736 and founded on the initiative of bishop Adam Rostowski [Bedyński 1994, 13-14; Nikołajew 2012, 21].

In 1767, Stanisław Lubomirski, the Grand Marshall of the Crown, established the Marshall prison in Warsaw. A military facility located at ul. Mostowa, which had previously served as an ammunition storage area, was used for this purpose. Thus, S. Lubomirski became also the author of the first prison regulations (prison ordinance) which contained an explicit provision on the right to religious care for the imprisoned. The prisoners were obliged to perform compulsory work. However, after completing their tasks, on Sundays and on holidays they could participate in masses and go to confession. The progressive character of the regulations was quite unparalleled. It even allowed for the prisoners to contact a priest of their own faith. The prison regulations emphasized that unrestricted contact of the prisoner with religious practices and a priest is the only way for their moral improvement. The Marshall prison was functioning until 1795 when, for the first time in the Polish prison system, a prison chapel appeared. The chapel was consecrated on 26th 1783 and the chaplain was a friar from the Order of Friars Minor Capuchin [RAFACz1932, 49;

regulaminu więziennego; ustawa z dnia 26 lipca 1939 r. o organizacji więziennictwa; instrukcja Ministra Bezpieczeństwa Publicznego z dnia 11 czerwca 1945 r. w sprawie regulaminu więziennego; zarządzenie Ministra Sprawiedliwości z dnia 14 grudnia 1956 r. w sprawie wykonywania posług religijnych w więzieniach. 
MaLeSZYK 2016, 21; JANIK 2016, 476; BedyŃSKi 1994, 14; NikOŁAJEW 2012, 22; SZYMAŃSKI 2016, 64-65].

In 1810, the document titled Urzadzenie więzien krajowych (Establishment of State Prions) (hereinafter called "Urządzenie") was drawn up for the first time to include the condition of the prisons in the Duchy of Warsaw. It was the first attempt to discuss comprehensive solutions in terms of the penal system. Among the factors that had a positive impact on the prisoners, the first was "religious practice" which was to improve their morals. The provisions of "Urządzenie" indicate that a day in prison was to start with a morning prayer, participation in the mass and listening to sermons and catechesis. After that the prisoners were to take part in moral teachings that lasted for an hour. "Urządzenie" also set high formal requirements concerning the function of prison chaplains. They were to be the most talented priests in a given diocese. However, the solutions adopted in the document had not been implemented due to the fall of the Duchy of Warsaw. However, "Urządzenie" has been seen as an example of a modern legal act taking the necessity of humanitarian prisoner treatment into account [BEDYŃSKI 1994, 18-20; NikoŁaJew 2012, 23-24; MaLESZYK 2016, 22; SzYMAŃsKi 2016, 65].

In 1818, the Kingdom of Poland witnessed the inspection of all prison facilities that were subject to the Internal Affairs Commission. Its results were included in a report compiled by Xawery Potocki of 6th March 1819. Based on the report, X. Potocki prepared the Projekt ogólnego i szczegółowego ulepszenia administracji i stanu więzień publicznych w Królestwie Polskim (Project of General and Detailed Improvement of the Administration and the Condition of the Public Prisons in the Kingdom of Poland). It contained the postulates to create chapels in prisons which would be the ideal places to give sacraments, organize masses, conduct catechesis, participate in joint prayers and hold conversations with prisoners. The prison chaplain was to celebrate liturgy, give sacraments, preach, organize common prayers and conduct catechesis and give moral lessons. The prisoners' responsibilities included participation in the sacraments, as well as the morning and evening prayer [Pотоскі 1929, 22-44; Migdal and RaglewsKi 2005, 88-89; MALESZyK 2016, 22; NiKoŁAJeW 2012, 24].

Although the Projekt had not been implemented, the tendencies connected with prison ministry were confirmed in a later Instrukcja więzienna (Prison Ordinance) issued on 17th September 1823. It was supplemented by a document published on 16th May 1833 titled Urzadzenie tymczasowe porzadku i karności więźniów dla więzień, w których fabryki sa zaprowadzone (Temporary Establishment of Order and Discipline of Prisoners for the Prisons Where Factories Are Established) [BedyŃski 1994, 20-22; MaLeszyK 2016, 22; Nikolajew 2012, 24; SzymaŃski 2016, 65-66]. 
Both Instrukcja więzienna and Urzadzenie tymczasowe did not take into the consideration the tasks of the chaplain in the process of spiritual care over the prisoners. The duties of the priest, who did not perform permanent service and was only called on ad hoc by the administration, were limited. The priest's tasks did not include a direct role in the education of the prisoners; he was only to perform pastoral services. Thus, under the provisions, such a priest could not have been seen as a chaplain. The great reformer of the Polish penitentiary system who disagreed with this model was count Fryderyk Skarbek. Since 1830 had been in charge of the Polish prison system. According to him, the prison chaplain should be fulfilling their mission during daily and individual contacts with the prisoners and not just performing ad hoc service [BEDYŃSKi 1994, 22-23; SENKowsKa 1961, 142-43; Nikolajew 2012, 24-25; MaLeszyK 2016, 22; SzYMaŃsKi 2016, 66-67].

Another legal act was Instrukcja dla więzień i zakładów karnych Królestwa Polskiego (Instruction for the Prisons and Correctional Facilities of the Kingdom of Poland) published in 1859. It governed all the functional aspects of prisons and penal institutions. It determined the conditions of priests' work, who in larger institutions were also called chaplains, remuneration for the prison chaplain ${ }^{2}$, obligations of taking part in religious practices by prisoners and the order of establishing a permanent chapel [BEDYŃSKI 1994, 24-25; NiKOŁAJEW 2012, 25; IDEM 2006, 18; MALESZYK 2016, 23; SZYMAŃSKi 2016, 67]. The chaplain had to organize morning and evening prayer with the prisoners, conduct catechesis and assist the convicts in the last journey to the execution. He was also a member of the prison administration [MALESZYK 2016, 23].

In the second half of 19th century, in many prisons of the Kingdom of Poland, the constant presence of a chaplain was provided. According to the statistical data, in 1881 twenty prisons of the former Kingdom of Poland employed 19 Roman Catholic priests, 15 pastors, 4 Eastern Orthodox priests and 2 deacons (Orthodox) [KACZYŃSKA 1989, appendix 16; BEDYŃSKi 1994, 25; SZYMAŃSKi 2016, 67].

In the Russian partition, diametrical changes in the prison ministry took place after 1867. The Russian Romanov dynasty deemed the religious service in prisons to be valuable but only when it was provided by Eastern Orthodox priests in the Russian language. Thus, Roman Catholic priests were banned from entering prisons and many of them were sent to Siberia. The chapels were turned into Orthodox churches ${ }^{3}$. Only the tolerant ukase of Nicholas II of 1905 allowed for the

\footnotetext{
${ }^{2}$ Increase of remuneration from 45 to 300 roubles.

${ }^{3}$ A large prison in Lublin was an exception to the rule. Due to the ban of repairing the Holy Trinity Church issued by the Russian authorities the Roman Catholic chaplains were allowed to enter it and the temple had not been turned into an Orthodox church [MALESZYK 2016, 23-24; NiKOlAJEw 2012, 25].
} 
reactivation of religious services provided by the Roman Catholic and Ukrainian Greek Catholic priests [MALEszyK 2016, 24; NikolaJew 2012, 26; IDEm 2006, 18].

In the Prussian partition, the prison ministry was governed by the prison ordinance of 1898 which included permanent employment of a prison chaplain (Catholic, Evangelist), as well as allowed for performing religious practices by the prisoners [NiKolajew 2012, 26; BeDyŃSKi 1994, 25-26].

In the Austrian partition, prisoners were allowed to perform religious practices and use religious services according to the multi-national and multi-religious tolerance rule of Austria-Hungary. An example of that rule was organizing ecumenical masses with the participation of Roman Catholic and Greek Catholic priests in the "Brygidki" prison in Lviv and the Holy Saturday mass in Mała Kasernia [BEDYŃSKI 1994, 26; SZYMAŃSKI 2016, 67; NiKoŁAJEw 2012, 26]. It should also be noted that in the Free City of Kraków the Christian denominations received privileged treatment, and other religious beliefs were described as "tolerable" [AJNENKIEL 2001, 109-13; Nikolajew 2012, 26].

\section{THE RELIGIOUS ASSISTANCE IN THE REPUBLIC OF POLAND 1918-1939}

In November 1918, the first task after having taken control over the prisons, was to save the lives of the imprisoned. The first account of that period regarding religious influence on the process of the penitentiary condition of the prisoner can be found in a decree signed by Józef Piłsudski on 8th February 1919 w sprawie tymczasowych przepisów więziennych ${ }^{4}$ (on temporary prison regulations). It described the formal status of the chaplain who became an employee of the prison system reporting to the bishop who had appointed that chaplain and the warden who became his superior in procedural matters. In other words, the chaplain was totally independent in terms of pastoral service and he reported to the prison warden only regarding adherence to procedural matters (Article 3). The prisoner's status was defined in the provision of Article 11 which stated that prisoners could take advantage of spiritual help provided by the priest of their denomination ${ }^{5}$. Those provisions were introduced to fight with the prisoners' atheism [MALESZYK 2016, 26].

Another historical provision of that period are two legal acts. The first one is the Regulation of the Minister of Justice of 20 April 1926 o zaspokajaniu

\footnotetext{
${ }^{4}$ Dekret Naczelnika Państwa z dnia 8 lutego 1919 r. w sprawie tymczasowych przepisów więziennych, „Dziennik Praw Państwa Polskiego” z 1919 r. Nr 15, poz. 202.

${ }^{5}$ Article 11 of the decree was as follows: "no prisoner is allowed to refuse participation in religious studies nor religious comfort given to them by a priest of their denomination" [MALESZYK 2016, 25; BedyŃsKi 1994, 29; NiKoŁAJEW 2012, 27].
} 
potrzeb religijnych więźniów i o działalności oświatowej, szkolnej i pozaszkolnej $w$ więzieniach ${ }^{6}$ (on meeting the religious needs of the prisoners and on educational, school and non-school activities in prisons) which made the priests responsible for the religious influence on prisoners. Furthermore, it said that every detainee had the right to satisfy their own religious needs. Moreover, juvenile delinquents, by the power of that regulation, were compelled to undergo religious education. The duty of the chaplains was to give sacraments and teach juvenile delinquents religion and ethics [BedyŃsKi 1994, 30-31; NiKoŁaJew 2012, 28; MALESZYK 2016, 26; SZYMAŃsKi 2016, 71]. Thus, 109 Roman Catholic chaplains were employed and in 117 prisons churches or chapels were established [BEDYŃSKI 1994, 30; NiKOŁAJEW 2012, 28-29]. The regulation also adopted a solution connected with employing prison chaplains (the candidates were to be chosen by the bishop, the warden was to sign an agreement with them and the agreement was to be approved by the head of the Criminal Department of the Ministry of Justice). It was also underlined that the warden, together with his assistant handling educational matters and the chaplain were responsible for the proper implementation of the religious service [NikolaJew 2012, 28].

The abovementioned legal acts were confirmed by the Regulation of the President of the Republic of Poland of 7th March 1928 w sprawie organizacji więziennictwa ${ }^{7}$ (on the organization of the prison system). Chapter V of that Regulation was titled: Opieka duchowna, oświatowa i pozaszkolna. (Religious, Educational and Non-School Care). For the first time a document has evoked to the influence on prisoners that may be exercised only by a priest. By the power of that Regulation Polish prisoners received the right to participate in masses provided that the respective authority did not object to that [Migdal 2011, 175-78; NiKolaJew 2012, 29; SZYMAŃSKI 2016, 71-72]. In 1925, the total number of prison chapels and churches was 117. There were 125 full-time employed prison chaplains [Migdat 2011, 178; IDEm 2012, 393-98]. Under the said Regulation of 1928, the Minister of Justice issued another regulation concerning its execution (rozporządzenie Ministra Sprawiedliwości z dnia 22 czerwca 1928 r. o wykonaniu rozporządzenia Prezydenta Rzeczypospolitej Polskiej z dnia 7 marca 1928 r. w sprawie organizacji

\footnotetext{
${ }^{6}$ Rozporządzenie Ministra Sprawiedliwości z dnia 20 kwietnia 1926 r. o zaspokajaniu potrzeb religijnych więźniów i o działalności oświatowej, szkolnej i pozaszkolnej w więzieniach, „Dziennik Urzędowy Ministra Sprawiedliwości” z 1916 r. Nr 9, poz. 10.

${ }^{7}$ Rozporządzenie prezydenta RP z dnia 7 marca 1928 r. w sprawie organizacji więziennictwa, Dz. U. z 1928 r. Nr 29, poz. 272.
} 
więziennictwa ${ }^{8}$ ) which indicated that the supervision over the spiritual care in prisons was handed over to the district prosecutor [NIKOEAJEW 2012, 29].

The second legal act was the Regulation of the Minister of Justice of 20 June 1931 $w$ sprawie regulaminu więziennego (on the prison regulations) that ordered the matters connected with different access of the prisoners of various denominations to the service organized in the prison chapel and recognized religious care as a basic educational and corrective instrument. Unfortunately, the regulation favoured the Roman Catholic denomination, which led to the protests of the Ukrainian prisoners who were detained in eastern Poland. Moreover, the regulation introduced the rule of protecting the authority of the religious acts. For a breach of discipline during the mass, morning or evening prayer, the prisoner was sent to the dark cell for two days. Staying there on bread and water, they had enough time to think on their condemnable behaviour [MALESZYK 2016, 27]. The availability of sociological research from that period indicates that the most numerous group of prisoners were, apart from Catholics, Jews and members of the Eastern Orthodox Church. However, rabbis and Orthodox priests were not employed in prisons, thus, they performed their services on a voluntary basis [NIKOŁAJEw 2012, 29-30]. In the opinion of the commentators of that period, the regulation was quite well drawn up. Thus, it is no surprise that it has survived the following years despite Poland's defeat in the war and the fact that it became an occupied land. However, the area of applicability of that regulation was rather narrow. It was not in force in the lands occupied by the Soviets. The priests could not enter any prisons located there. The Polish captives being murdered in spring of 1940 by the NKVD were not allowed to meet with a priest even right before their execution [MALESZYK 2016, 27].

Based on the provisions of the said regulation, the Minister of Justice established an institution for larger prisons called the Prison Committee. It was a social body whose basic purpose was to cooperate with the penal administration in terms of the influence on the execution of the punishment and post-penal assistance. The prison chaplain, who was the centre of the actions connected with the moral support over the prisoners and former convicts, played the key role here [BEDYŃSKI 1994, 31-32; Nikolajew 2012, 29-30; Maleszyk 2016, 26-27; Plisiecki 2016, 52-54; SZYMAŃSKi 2016, 72-74; LASOCIK 1993, 86; Migdal 2012, 398-403].

\footnotetext{
${ }^{8}$ Rozporządzenie Ministra Sprawiedliwości z dnia 22 czerwca 1928 r. o wykonaniu rozporządzenia Prezydenta Rzeczypospolitej Polskiej z dnia 7 marca 1928 r. w sprawie organizacji więziennictwa, Dz. U. z 1928 r. Nr 64, poz. 591.

${ }^{9}$ Rozporządzenie Ministra Sprawiedliwości z dnia 10 czerwca 1931 r. w sprawie regulaminu więziennego, „Dziennik Urzędowy Ministra Sprawiedliwości” z 1931 r. Nr 71, poz. 577.
} 
The last legal act concerning the prison system in that period was the Act of 26 July 1939 o organizacji więziennictwa ${ }^{10}$ (on the organization of the prison system) that came into effect on 1st September 1939. It played a major role because the previous normative acts were only of a regulatory character. Its fifth chapter titled "Moral and Religious Care" described the role of the ministry in prisons. Based on the provisions of the Act, the prison chaplain was a member of the prison staff and was responsible for the conditions of the religious care exercised over the detained. In turn, the prisoners could practice their own religion and take part in masses organized in prison. Moreover, the Act allowed the Minister of Justice to appoint the priests of other denominations than the Roman Catholic as prison priests. Hence, in practice in the mid-1930s the prisons employed 142 chaplains. In smaller prisons the religious and moral care over the detained was provided by non-resident priests [Migdal 2012, 403-405; BedyŃsKi 1994, 32-33; NiKoŁaJEW 2012, 30-31; SZYMAŃSKI 2016, 74-75].

\section{THE RELIGIOUS ASSISTANCE}

DURING THE TIME OF TWO TOTALITARIAN SYSTEMS 1939-1956

During the German occupation (1939-1944) and the Russian occupation (19391941) the events of prison chaplain martyrdom and their participation in the resistance movement, the possibility of providing religious services in occupational prisons and their performance in practice and the forms of religious life of the prisoners, had a major impact on the implementation of tasks connected with the prison ministry. The situation was very different in the lands incorporated into the Reich, the General Governorate and the areas seized by the USSR after 17th September 1939 [BedyŃsKi 1994, 39; Nikolajew 2012, 31; MaleszyK 2016, 27].

In 1940, in the Polish lands incorporated into the Third Reich, special prison regulations (polizeigefangnisordung) that prohibited the performing of religious acts by detained Poles, were introduced. Among the prison staff there was no prison chaplain. Providing religious services in prison was punishable by death. Only in justified cases could the priests participate in the executions [MALESZYK 2016, 27; NiKoŁAJEW 2012, 32; IDEM 2009, 29; BeDYŃSKi 1994; 44].

At first, within the General Governorate the Germans tolerated the presence of priests and the religious service provided by them for the benefit of the prisoners. However, the situation changed starting from 1940. After the interventions of the Eastern Orthodox Church leaders, the Catholic priests were prohibited from per-

\footnotetext{
${ }^{10}$ Ustawa z dnia 26 lipca 1939 r. o organizacji więziennictwa, Dz. U. Nr. 68, poz. 457.
} 
forming religious service in prisons in Warsaw. The consent to perform ministry tasks for the prisoners was only given to the Eastern Orthodox priests and they were allowed to provide it only for the prisoners of their denomination. There was an absolute ban of performing any religious acts for the Jews. The detained priests were absolutely prohibited from performing masses and giving sacraments. The function of the chaplains was often performed by the detained priests themselves, and if there were no such priests, then the prisoners who enjoyed the highest moral authority. The entire prison ministry had to hide, and any religious service was performed in conspiracy [NIKOŁAJEw 2012, 32-33]. The memoirs of former prisoners from the occupational period are filled with the descriptions of group singing of religious songs in prison cells. A prison litany to Our Lady was recited and it included such new invocations as: "the Mother of awaiting families", "the Queen of those who are sentenced to death - pray for us". In 1943, in a cell of the Pawiak prison, Elżbieta Krajewska wrote her piece titled „Droga krzyżowa Polaków w więzieniach i obozach" (The Way of the Cross of Poles in Prisons and Camps). Some members of the prison staff were involved in the secret prison ministry. The confession was organized in every available venue. Lay people were smuggling the Holy Sacrament into prisons and gave Holy Communion to the prisoners using various industrious methods. The perfect example is sub-commissioner Wanda Gawryłow who carried Holy Communion from St. Charles Borromeo's Church to the Pawiak prison in a special medallion and a powder compact. The same person was also the godmother of a child born in the prison hospital in Pawiak in January 1943. Another exceptional example is the attitude of a detained chaplain, St. Maksymilian Maria Kolbe, who gave his own life for a fellow-prisoner with a family [Nikolajew 2012, 32-33; BedYŃski 1994, 44-55; MALESZYK 2016, 27-28].

In the areas occupied by the USSR, there were no legislative means nor proper staffing allowing the prisoners to perform religious practice and use spiritual care. It was connected with the anti-religious and anti-Polish Soviet system. Thus, the NKVD officers favouring the communist system or those of Jewish origin were employed in prisons. The occupiers persecuted prisoners who manifested their religious beliefs. For instance, on Christmas Eve and on Good Friday the prisoners were given soup with meat. Detained chaplains had to provide religious service in secret (also hiding that fact from other prisoners). The religious life of the prisoners was manifested by items used for religious practices and performed in conspiracy, especially crosses [BEDYŃsKi 1994, 55-60; NiKOŁAJEW 2012, 33-34; MALESZYK 2016, 28-29].

By mid 1945 the formal provisions of 1931 were in force. Only on the basis of the instruction issued by the Minister of Public Safety of 11 June 1945 w sprawie 
regulaminu więziennego ${ }^{11}$ (on prison regulations) the chaplain was removed from the prison staff, and, at the same time, instead of religious and moral influence the ideological and political impact was introduced [BEDYŃSKI 1994, 61-70; NIKOŁAJEW 2012, 34-35]. Zigniew Lasocik calls the Instruction "a censored version of the prison regulations of 1931" [LASOCIK 1993, 95].

The instruction discontinued the functioning of the Regulation of 1931 and the solutions adopted therein. It allowed for prayer in the prison cell or the chapel but only to the convicted prisoners. Religious services in prison could only be provided by the diocesan chaplains. However, it excluded the possibility of paying visits to the prisoners by the monks. The consent to provide religious services in prison was given by central authorities after having submitted an application to the prison warden and the church authorities. Most frequently, those applications were rejected or weren't processed at all. Because of the impossibility of providing religious services, the bishops had to be really industrious in that regard. For instance, because a priest could not enter a prison to perform Viaticum, the bishop of Sandomierz, Jan Lorek, in his writ to the Head of the Prison and Camp Department of 12 December 1945 wrote: "I appoint reasonable priests to work in prisons and I order them to strictly perform only their religious duties, not meddling in any other matters that are none of their business" [BEDYŃSKi 1994, 65].

In practice, even this rigorous Instruction was not adhered to. Thus, very sporadically the priests were called to witness executions and sometimes they weren't even allowed to perform the last rites before the execution. Moreover, the Instruction ordered closing prison chapels [MALESZYK 2016, 28-29].

Religious service in prisons was restored under the decision of the Prison and Camp Department of 1 April 1946. Services could only be performed by the Roman Catholic priests. The status of other religious denominations was decreased due to historical reasons. And so, the Eastern Orthodox church was groundlessly perceived as a marginal religion, dominant only for the persons who had been displaced from the areas east of the Bug River. The protestants were identified with Germans. The extremist policy adopted against Jews during the Second World War prevented the reactivation of the Jewish religious structures and the Jews saved from the Holocaust often became conformists in the new political reality [NiKolajew 2012, 35]. At the beginning of 1947, the Department was in charge of 131 prisons and camps. Only four of them employed chaplains and the rest could only be visited by non-residing priests [BEDYŃSKI 1994, 70].

\footnotetext{
${ }^{11}$ Instrukcja Ministra Bezpieczeństwa Publicznego z dnia 11 czerwca 1945 r. w sprawie regulaminu więziennego (not published).
} 
The importance of prison ministry increased once more along with the signing on 14 April 1950 of the Understanding by and between the Government and the Episcopate of Poland ${ }^{12}$. It was signed after long negotiations. The content of the Understanding included a preamble and 19 articles concerning the issues of interest both to the Church and to the state [MiszTaL 1997, 197-202]. One of the provisions stipulated that the religious care over the prisoners was to be performed by the chaplains appointed by respective resort authorities upon the bishop ordinary's request (no. 17). The chosen chaplains had a difficult task before them. On one hand, they were under the surveillance of the UB and, on the other, they met with distrust of the prisoners suspecting them of providing their services to the resort ("patriot priests"). Moreover, the penal staff themselves were ordered to show their dislike towards the chaplains [BEDYŃSKI 1994, 72-76; NiKOŁAJEW 2012, 36; MALESZYK 2016, 29].

Unfortunately, the text of the Understanding of 1950 was published only in the press ("Trybuna Ludu") and in the internal journals of the Church ("Miesięcznik Kościelny Archidiecezji Poznańskiej”, "Gorzowskie Wiadomości Kościelne”). Right after signing of the Understanding, the government established the Office for Religious Affairs which interfered with the internal matters of religious denominations, especially the Catholic Church [MiszTaL 1997, 201-204].

In another understanding of 14 April 1956 by and between the Government and the Episcopate of Poland ${ }^{13}$ the provisions connected with the prison ministry contained in the Understanding of 1950 were confirmed. Moreover, it defined the rules of religious care over prisoners and appointment of the prison chaplains. Undoubtedly, the Understanding of 1956 was a step forward in terms of religious influence on the prisoners. The state limited its illegal impact on the internal matters of religious denominations, especially the Catholic Church. However, it was a strategic move; thus, the prison authorities did not issue any respective implementing measures in line with the Understanding of 1956 [BEDYŃsKi 1994, 76-81; Nikolajew 2012, 37; MaleszyK 2016, 29; Misztal 1997, 246-48].

Only on 14th December 1956 the Minister of Justice issued an order $w$ sprawie wykonywania postug religijnych $w$ więzieniach ${ }^{14}$ (on exercising religious services

\footnotetext{
12 Porozumienie między Rządem RP a Episkopatem Polski, in: Listy pasterskie Episkopatu Polski 1945-1974, Paris: Ėditions du Dialogue 1975, pp. 91-97; Porozumienie can also be found in: Państwowe prawo wyznaniowe Polskiej Rzeczypospolitej Ludowej. Wybór tekstów źródłowych, ed. M. Fąka. Warszawa: Akademia Teologii Katolickiej, 1978, pp. 26-27.

${ }^{13}$ See Komunikat Komisji Wspólnej przedstawicieli Rządu i Episkopatu z 8 XII 1956 r. o zasadach uregulowania wzajemnych stosunków, in RaINA 1994, 575-76; see also Komunikat Komisji Wspólnej z 8 XII 1956, „Wiadomości Diecezjalne Łódzkie” 7 (1956), pp. 176-77.

${ }^{14}$ Zarządzenie Ministra Sprawiedliwości z dnia 14 grudnia 1956 r., nr. 80 (not published).
} 
in prisons). An analysis of that document indicates that the adopted solutions further limited the right of a believing prisoner to use the spiritual care and varied from the regulations adopted in the Understanding of 1956. Convicted prisoners still had no right to participate in religious meetings. The presence of a priest in prison concerned only military chaplains with limited access to prisoners and only in some correctional facilities mentioned in Attachment no. 1. The status of the chaplain remained undefined. Probably, he was to perform that function free of charge [Migdal 2008, 386; NikoŁajew 2012, 37-38; MaleszyK 2016, 29; Misztal 1997, 245; see more: Migdal 2007]. The responsibilities of the chaplain in the correctional facility included organizing masses, granting confessions during Easter and providing other religious service upon the request of seriously ill prisoners $(\S 3)$. The scope of the service was limited to the activities typical for a chaplain, and it was only reserved for the convicts. The temporarily detained, also called the detained due to the pending investigation, had to obtain consent from the respective public authorities each time. Moreover, the prison warden was informed by the Public Safety Offices of candidates for the position of the prison chaplain. Afterwards, the warden should sign an appropriate agreement with such a candidate. Thus, government officials appointed the chaplains themselves despite the formal selection of the candidate by the bishop. The Understanding itself, instead of unifying the administration with the priests, resulted in creating various divisions [NIKOŁAJEW 2012, 37-38].

\section{CONCLUSION}

The history of the prison chaplaincy in Poland was quite turbulent. The legal acts issued derived from the policy of the governing authorities of the Republic of Poland. The entire history of the prison chaplaincy described in the article focused around two fields: the legal status of the prisoner and the legal status of the chaplain. It should be noticed that the situation of prisoners was strongly depended on their denomination. On the basis of the discussed periods we can notice that the most repressive legal acts against the prisoners were issued during the German and Soviet occupation. It seems to be obvious the most privileged denomination in the prisons and other prison facilities was the Roman Catholic. 


\section{REFERENCES}

AjNEnKIEL, Andrzej. 2001. Konstytucje polski w rozwoju dziejowym 1791-1997. Warszawa: Oficyna Wydawnicza Rytm.

BedyŃsKi, Krystian. 1994. Duszpasterstwo więzienne w Polsce - zarys historyczny. Warszawa: First Business College.

Czacki, Tadeusz. 1800. O litewskich i polskich prawach. Warszawa [s.n.].

JANIK, Piotr. 2016. „Działalność ewangelickiego duszpasterstwa więziennego w Polsce.” W Wolność sumienia i religii osób pozbawionych wolności. Aspekty prawne i praktyczne, red. Jerzy Nikołajew, i Konrad Walczuk, 476. Siedlce: Wydawnictwo. Diecezji Siedleckiej Unitas.

KaCZyŃSKA, Elżbieta. 1989. Ludzie ukazani. Więzienia i system kar w Królestwie Polskim 1815-1914. Warszawa: Wydawnictwo Naukowe PWN.

Lasocik, Zbigniew. 1993. Praktyki religijne więźniów. Warszawa: Wydawnictwo Naukowe PWN.

MALESZYK, Ryszard. 2016. „Historyczne aspekty kształtowania się prawa więźniów do wolności religijnej." W Wolność sumienia i religii osób pozbawionych wolności. Aspekty prawne i praktyczne, red. Jerzy Nikołajew, i Konrad Walczuk, 21. Siedlce: Wydawnictwo. Diecezji Siedleckiej Unitas.

Migdal, Jerzy, i Janusz Raglewski. 2005. Kara pozbawienia wolności. Zarys dziejów polskiej doktryny, prawa i polityki penitencjarnej. Gdańsk: Arche.

Migdal, Jerzy. 2007. Polski system penitencjarny lat 1944-1956. Gdańsk: Arche.

Migdat, Jerzy. 2008. Polski system penitencjarny w latach 1956-2008 w ujęciu doktrynalnym, normatywnym i funkcjonalnym. Kontynuacja czy zmiana?. Gdańsk: Arche.

Migdal, Jerzy. 2011. Polski system penitencjarny w latach 1918-1928. Gdańsk: Arche.

Migdal, Jerzy. 2012. Polski system penitencjarny w latach 1928-1939. Gdańsk: Arche.

Misztal, Henryk. 1997. Polskie prawo wyznaniowe. Zagadnienia wstępne. Rys historyczny. T. I. Lublin: Redakcja Wydawnictw KUL.

NikoŁAJEw, Jerzy. 2006. „Opieka religijna realizowana w więzieniu w ujęciu historycznym.” W Nauczanie papieża Jana Pawła II do więźniów i stużb penitencjarnych, red. Józef Świtka, i Monika Kuć, 18. Lublin: Wydawnictwo KUL.

Nikolajew, Jerzy. 2009. Duszpasterstwo więzienne. Tradycje, teraźniejszość, perspektywy. Lublin: Polihymnia.

NikoŁAJew, Jerzy. 2012. Wolność sumienia i religii skazanych i tymczasowo skazanych. Lublin: Wydawnictwo KUL.

PLISIECKI, Marek. 2016. „Opieka duchowa w założeniach więziennictwa II Rzeczypospolitej.” W Wolność sumienia i religii osób pozbawionych wolności. Aspekty prawne i praktyczne, red. Jerzy Nikołajew, i Konrad Walczuk, 52-54. Siedlce: Wydawnictwo. Diecezji Siedleckiej Unitas.

Ротоскі, Xawery. 1929. „Uwagi do ogólnego i szczegółowego ulepszania administracji i stanu więzień publicznych w Królestwie Polskim.” W Księga Jubileuszowa więziennictwa polskiego 1918-1928, red. Zygmunt Bugajski, 22-44. Warszawa: Związek Pracowników Więziennych Rzeczypospolitej Polskiej.

RAFACZ, Józef. 1932. Więzienie marszałkowskie w Warszawie w latach 1767-1795. Lwów: Drukarnia Uniwersytetu Jagiellońskiego pod zarządem J. Filipkowskiego.

RaIna, Peter. 1994. Kościót w PRL. Kościót katolicki a państwo w świetle dokumentów 1945-1989. T. I: Lata 1945-59. Poznań: Wydawnictwo W drodze.

SenkowsKa, Monika. 1961. Kara więzienia w Królestwie Polskim w pierwszej połowie XIX wieku. Wrocław: Zakład Narodowy im. Ossolińskich. 
SzYMAŃSKI, Andrzej. 2016. „Kapelani więzienni w II Rzeczypospolitej - zarys problematyki.” W Wolność sumienia i religii osób pozbawionych wolności. Aspekty prawne i praktyczne, red. Jerzy Nikołajew, i Konrad Walczuk, 64-65. Siedlce: Wydawnictwo. Diecezji Siedleckiej Unitas.

\title{
HISTORICAL OVERVIEW OF PASTORAL CARE IN PRISON IN POLAND (1550-1956)
}

\begin{abstract}
Sum mary
The entire history of pastoral care in prison presented in this article focused on two dimensions: the prisoner's legal situation (his rights and duties as a prisoner) and the legal situation of the prison chaplain. Until 1918, prison chaplaincy concentrated on performing the religious assistance and building new prison chapels. Subsequently, in the second period (1918-1939), based on the rozporzadzenie Prezydenta Rzeczypospolitej z dnia 7 marca 1928 r.w sprawie organizacji więziennictwa, Polish prisoners obtained the right to participate in religious services. The next legal act [rozporzadzenia Ministra Sprawiedliwości z dnia 20 czerwca 1931 r.w sprawie regulaminu więziennego] issued in 1931, allowed to sort out matters related to the access of prisoners of various denominations to the religious ministry in the prison chapel. The Act of 26 of July of 1939 on the organization of penitentiary institutions [ustawa $z$ dnia 26 lipca 1939 r. o organizacji więziennictwa] has significant role. The evolution of prison chaplaincy during the Soviet and German occupation was also presented. At least, the special attention was paid to the agreement of 14 of April 1950 concluded between the communistic Government and the Polish Episcopate.
\end{abstract}

Key words: prison chaplaincy; religious assistance; spiritual care; prison regulations

\section{PRZEGLĄD HISTORYCZNY OPIEKI DUSZPASTERSKIEJ W WIEZIENIU W POLSCE (1550-1956)}

Streszczenie

Historia opieki duszpasterskiej w więzieniu przedstawiona w niniejszym artykule dotyczy dwóch wymiarów: sytuacji prawnej więźnia (jego prawa i obowiązki) oraz sytuacji prawnej kapelana więziennego. Do 1918 r. kapelan więzienny koncentrował swoje wysiłki na pomocy religijnej i budowie nowych kaplic więziennych. Następnie w drugim okresie (1918-1939) na podstawie rozporządzenia Prezydenta Rzeczypospolitej z dnia 7 marca 1928 r. w sprawie organizacji więziennictwa, polscy więźniowie uzyskali prawo do uczestnictwa w nabożeństwach. Na mocy kolejnego aktu normatywnego wydanego w $1931 \mathrm{r}$. rozstrzygnięte zostały kwestie dostępu więźniów różnych wyznań do posługi religijnej w kaplicy więziennej. Istotną rolę odegrała ustawa z 26 lipca 1939 r. o organizacji więziennictwa. W artykule przedstawiona została również ewolucja kapelaństwa więziennego w czasie okupacji sowieckiej i niemieckiej. Wreszcie uwagę zwrócono także na porozumienie z dnia 14 kwietnia 1950 r. zawarte między rządem komunistycznym a Episkopatem Polski.

Słowa kluczowe: kapelan więzienny; pomoc religijna; opieka duchowa; przepisy więzienne 